\title{
Green Tropical Phytoextracts - Promising Anticancer Alternative
}

\author{
Abid Ali Khan ${ }^{1,2}$; Kosar Ali Omer²; Ayesha Talib'; Haroon Ahmed'; Mohamad Arshad \\ Javed $^{3 *}$; Roji Mohamad Sarmidi ${ }^{2 *}$. \\ ${ }^{1}$ COMSATS Institute of Information Technology, Department of Biosciences, Islamabad, Pakistan; ${ }^{2}$ Universiti \\ Teknologi Malaysia, Institute of Bioproduct Development, Skudai, johor, Malaysia; ${ }^{3}$ Department of Industrial \\ Biotechnology, Faculty of Biosciences \& Bioengineering, Universiti Teknologi Malaysia, 81310 Johor Bahru, \\ Malaysia.
}

\begin{abstract}
The anticancer potential of aqueous extracts of tropical plants Ficus deltoidea and Labisia pumila were tested on human prostate carcinoma (DU145) cells. The effects of these extracts on the cells were observed through several tests such as cytotoxicity MTT assay, trypan blue exclusion assay (for cell viability), fluorescence and morphological observations. Both of the plant extracts had a growth repression effect on the cells with different concentrations. The best concentration $\left(1 \times 10^{-3} \mu \mathrm{g} / \mathrm{mL}\right)$ was chosen by determining their cytotoxic effects on human prostate cancer as well as fibroblast (normal) cells. The F. deltoidea extract showed more potency and killed the cells faster than L. pumila. Morphologically both extracts affected the cells in a similar way, i.e. the cells became irregular shaped, detached themselves and kept floating in the medium.
\end{abstract}

Key words: Labisia pumila; Ficus deltoidea; Anticancer Plant Extract; Prostate cancer.

*Authors for correspondence: mroji@ibd.utm.my 


\section{INTRODUCTION}

Plants have been serving mankind from time immemorial. They provide remedies and cure for their diseases even today. Plant derivatives and their natural products encompass over $50 \%$ of all the drugs being used clinically (1-3). A large proportion $(\sim 80 \%)$ of world's population is still dependent on traditional medicine, which mostly consists of plant extracts or derivatives, for primary health care and treating different diseases (4-6). The development of resistance of microorganisms towards antibiotics and other chemical therapeutics has also enforced the idea of finding medicinal plants with antimicrobial activities. All over the world, 121 clinical drugs have been isolated from plants, most of them made their inroads from traditional medicine (7). During the late 1960s, Hartwell published a series of articles for a period of over five years in journal Lloydia. This embarked the first series of articles which included information over 3000 plant species which had the potential to act as natural anticancer agents (8-10). Malaysia is a tropical country that harbours a rich variety of medicinal plants. Currently Malaysia is among 12 mega biodiversity-rich countries in terms of number of plant species (Institute for Medical Research, 2002). The well-known herbs that are being studied meticulously are Eurycoma logifolia (Tongkat Ali), Labisia pumila (Kacip Fatimah) and Ficus deltoidea (Mas Cotek) owing to their use for a long time in traditional medicine by the natives (11).

F. deltoidea is a shrub that belongs to the family of Moracea (12). This species has a vital role in traditional medicine as different parts of the plant are used in treatment of several ailments such as the fruit used for headache relief and it is also chewed in case of toothache. Dried powdered roots and leaves are used as external applicants for sores and wounds. The leaves are tied onto joints for relief of rheumatism and herbal drink is consumed by women after child birth to assist uterus strengthening $(13,14)$. Flavonoids are the fundamental chemical compounds of $F$. deltoidea. It has been reported that herbs which contain flavonoids have the ability to act as antiinflammatory, antiallergy, anticancer and antimicrobial agents (15-17).

L. pumila locally known as Kacip Fatimah is considered as the queen of herbs in Malaysia. It belongs to the Myrsinaceae family and looks like a small woody and leafy plant that inhabits South East Asia and other tropical forests (18). Generations of Malay women took this extract for facilitating child birth by contracting uterus (19). Malaysian females still use plant extracts of $L$. pumila for treatment of diseases of the reproductive system, to regulate the menstrual cycle and sexual function enhancement. Males and females from many ethnic groups of Sarawak in Malaysia use it to maintain and increase stamina $(18,20)$. L. pumila has been reported to have phytoestrogen in abundance. Phytoestrogen mimics the action of estrogen by inhibiting the growth of prostate cancer cell lines (21).

Prostate cancer is one of the common diagnosed cancer worldwide, especially in the Western societies. Approximately one in seven men has the probability to develop prostate cancer and this makes it most common cancer in the United States. In the United States, about 589,430 are expected to die out of 1,658,370 newly diagnosed cancer (22) while it was predicted to be total of $1,359,100$ cancer deaths in Europe in 2015 (23). Prostate cancer, which is the third cause of male cancer mortality in the Europe has the predicted rate at $10.2 / 1,00,000$ men with a $10 \%$ fall since 2009 (24). According to GLOBOCAN 2008 (a project of the International Agency for Research on Cancer), prostate cancer was the second most diagnosed cancer among males, the $5^{\text {th }}$ common cancer overall, and the $6^{\text {th }}$ leading cause of death in men due to cancers worldwide (25).

In this article we report the effect of aqueous extracts of F.deltoidea and $L$. pumila human prostate carcinoma and human skin cell lines to determine their cytotoxic effect on the cell viability and morphology. To the best of our knowledge this is the first study on the effect of $F$. deltoidea on human prostate cancer.

\section{MATERIALS AND METHODS}

\section{Materials}

The aqueous extracts of $F$. deltoidea and $L$. pumila were prepared in water. Dried leaves in powdered form were mixed with distilled water in the ratio of $1: 10$, i.e. $100 \mathrm{~g}$ of leaf extracts were mixed in $1 \mathrm{~L}$ water. The mixture was stirred and then sonicated (QSonica) using ultrasound cleaning $(50 \mathrm{kHz}, 60$ $\left.{ }^{\circ} \mathrm{C}\right)$ for $5 \mathrm{~min}$. The solution was passed through a filter paper (Whatman, England) and the liquid present in the filtrate was evaporated using a rotary 
evaporator (Cole Parmer). The crude extract was dried in an oven and stored at $-20^{\circ} \mathrm{C}$.

The crude extract powder was dissolved in $10 \mathrm{~mL}$ of the DMEM (Dubecco's Modified Eagle's Medium) (Sigma Aldrich), the suspension was homogenized by using vortex then sterilized by 0.2 $\mu \mathrm{m}$ (Whatman) filter. Nine different concentrations of the extracts were prepared $(1000,100,10,1,0.1$, $0.001,0.0001,0.00001,0.000001) \mu \mathrm{g} / \mathrm{mL}$ for both plants.

\section{Cell lines}

Human Prostate Carcinoma cell line DU145 catalogue number HTB-81 was purchased from ATCC, United States. The cell line was derived from metastatic site in brain of 69 years old Caucasian male. HSF1184 cells (to be used as a control) (Catalogue number 90011883) derived from normal Caucasian human skin cells were purchased from ECACC, United Kingdom. Cells were cultured in DMEM supplemented with $10 \%$ Foetal Bovine Serum, and $1 \%$ penicillinstreptomycin in static $75 \mathrm{~cm}^{2}$ T-flask (Cellstar, Germany). The cells were incubated in a humidified atmosphere with $5 \% \mathrm{CO}_{2}$ at $37^{\circ} \mathrm{C}$.

\section{Normal growth curve of DU145 cell line}

Cells were seeded in fourteen 6-well plates with a concentration $1 \times 10^{-5}$ cells/well. The plates were incubated at $37^{\circ} \mathrm{C}$ in a humidified atmosphere of $5 \% \mathrm{CO}_{2}$, one plate was taken out daily. The media was aspirated and collected in centrifuge tube. Typsin-EDTA was used to detach remaining attached cells from culture plates. The cells were centrifuged, supernatant was removed and the pellet was resuspended in $1 \mathrm{~mL}$ of fresh DMEM. The cells were stained using $(0.2 \%)$ trypan blue. The viable and dead cells were counted using a hemacytometer (Hausser, USA) under a microscope (26). This procedure was repeated daily until all the cells died.

\section{Cell cytotoxicity (MTT) assay}

DU145 and HSF1184 cell lines were seeded in two 96-well plates for each of the line with a concentration of $4 \times 10^{-4}$ cells/well. The cells were incubated for 4 days to let them reach the exponential phase before treating them with the plant extracts. After incubation 10 different concentrations $(1000,100,10,1,0.1,0.001,0.0001$, $0.00001, \quad 0.000001, \quad 0.0000001 \mu \mathrm{g} / \mathrm{mL})$ of F.deltoidea extract with the media (supported with $1 \%$ of FBS) were added to the wells. The last wells were used as controls and no extracts were added to them. Same procedure was repeated for the $L$. pumila extract. The plates were incubated for another $48 \mathrm{~h}$. The MTT reagent was prepared $(0.5$ $\mathrm{mg} / \mathrm{mL}$ in sterile PBS) and $10 \mu \mathrm{L}$ of the reagent was added to each well and incubated for $4 \mathrm{~h}$. Afterwards both, the medium and MTT solution were removed and $200 \mu \mathrm{l}$ of DMSO (dimethyl sulfoxide) was added to each well and incubated for 5 min to allow dissolution of the purple MTTformazan crystals. The absorbance was measured at wavelength of $570 \mathrm{~nm}$ with microplate reader (ELx808, BioTek, USA) within one hour after adding MTT solvent (26).

\section{Cells viability assay}

The cells were seeded in fourteen "24-well plate" with a concentration of $4 \times 10^{-4}$ cell/well, incubated for $48 \mathrm{~h}$ to let the cells adhere to the plates. The first row of wells was treated with the $F$. deltoidea and second with the L. pumila extract with the most effective concentration that was calculated through MTT assay and the third row without any extract (only DMEM was added to it). The plates were incubated at $37{ }^{\circ} \mathrm{C}$ in a humidified atmosphere of $5 \% \mathrm{CO}_{2}$. One plate was taken out daily and the same procedure was repeated as discussed in section 2.4 for the cells till their death.

\section{Morphological study Imaging via inverted microscope}

The morphology of the cells was monitored continuously during the viability assay. Cells were observed under the inverted microscope at a $10 \mathrm{X}$ magnification and were digitally imaged. The aim of the study was to monitor the changes in the morphology of the cells under the effect of the addition of plant extracts during growth and follow until their death.

\section{Imaging via fluorescence microscope}

Cells with a concentration of $2.5 \times 10^{5}$ cells/well were seeded in 6-well plate and incubated for $48 \mathrm{~h}$. First two wells were treated with the $F$. deltoidea and the next two with $L$. pumila aqueous extracts, both with a concentration of $1 \times 10^{-3} \mu \mathrm{g} / \mathrm{mL}$. The fresh medium was added in last two wells as negative control. The plates were incubated for another $48 \mathrm{~h}$ at $37^{\circ} \mathrm{C}$ in a humidified atmosphere of $5 \% \mathrm{CO}_{2}$.

Apoptotic body formation was started after incubation as described by (27). The medium aspirated from the wells was transferred to the centrifuge tube and the attached cells were 
trypsinized and transferred to the same centrifuge tube. The cells were centrifuged at $1000 \mathrm{~g}$ for $5 \mathrm{~min}$. The supernatant was removed and the pellet was washed with $1 \mathrm{~mL}$ of cold PBS once. The pellet was resuspended with $25 \mu \mathrm{L}$ of cold PBS and $2 \mu \mathrm{L}$ EB/AO (Ethidium Bromide/Acridine Orange) dye mixture. Stained cell suspension was placed on a clean microscope slide and covered with a cover slip. Cells were observed using Nikon Inverted Fluorescence microscope at 40X magnification with excitation filter $480 / 30 \mathrm{~nm}$; dichromatic mirror cut-on $505 \mathrm{~nm} \mathrm{LP}$; and barrier filter 535/40 nm (27). Images were recorded with a Nikon COOLPIX digital camera.

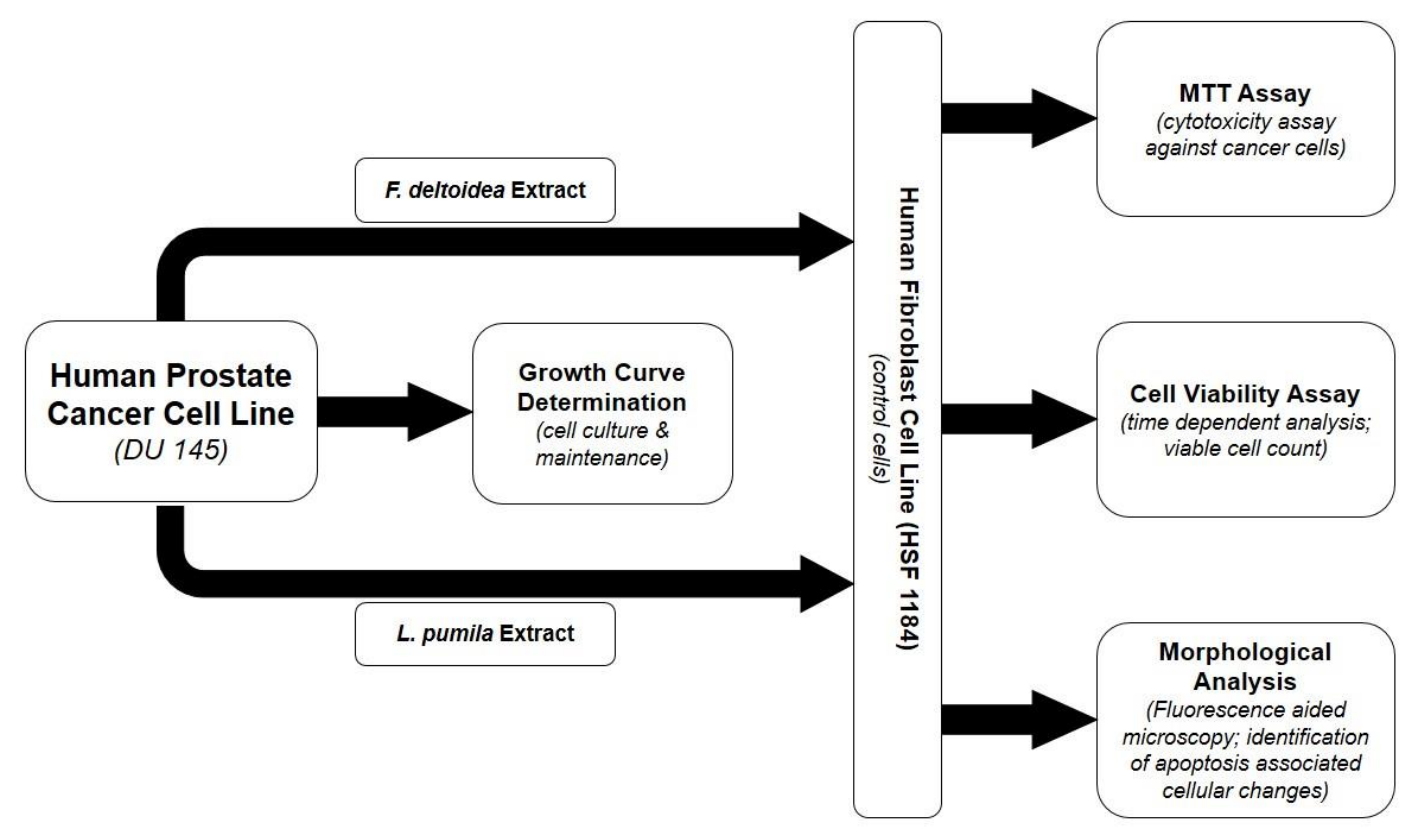

Figure 1: Schematic representation of the experimental studies in this report. DU 145 cells were grown and maintained by determining their growth curve. The cultured cancer cells were treated with aqueous extracts of $F$. deltoidea and L. pumila along with human fibroblast (HSF 1184) cells as control. The cancer (DU 145) as well as normal (HSF 1184) were analysed under the effect of the tropical plant extracts for MTT, cell viability and apoptotic (morphological) tests.

\section{RESULTS}

\section{Normal cell growth profile of Du145 cell line}

The growth profile of a cell determines its life span and doubling time. It also calculates the number of days required to thrive in sufficient number of cells for further analysis.

The growth of DU145 cells was followed over a span of 14 days. It can be divided into four phases namely, the lag phase, the log phase, the stationary phase and death phase as given in Figure 2. 


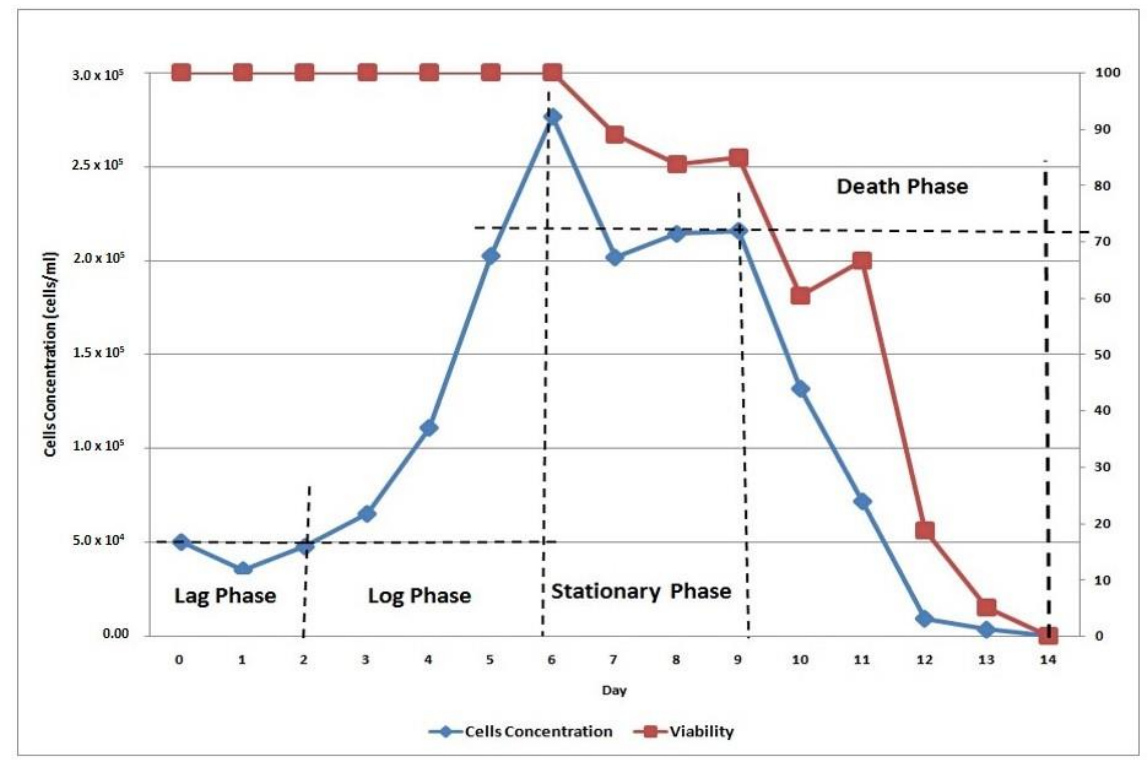

Figure 2: The complete growth profile of DU145 cell line

It is evident from Figure 2 that the cells had a lag phase of 2 days and they started thriving at a rapid pace day 2 onward reaching their log phase on day 3. They continued to grow logarithmically (exponentially) for the next 3 days, i.e. day 4-6. The measured growth curve for DU145 cell line in this study is in agreement with previous reports published for prostate cancer cells (28). This fact has been further verified by our growth curve (Fig. 2 ). The cells reached the stationary phase on day 8 while day 9 kicked-off the death phase and within the next 5 days (day 14) all cells died and the cell viability became zero.

\section{MTT assay}

The antiproliferative potential of the plant extracts was performed through MTT cytotoxicity assay, widely used to screen for cytotoxic compounds during the development of chemotherapy or to screen for the cytotoxic effect of a compound during preclinical studies (29). The profile of cell growth after treatment with the plant extracts is showed in Figure 3.

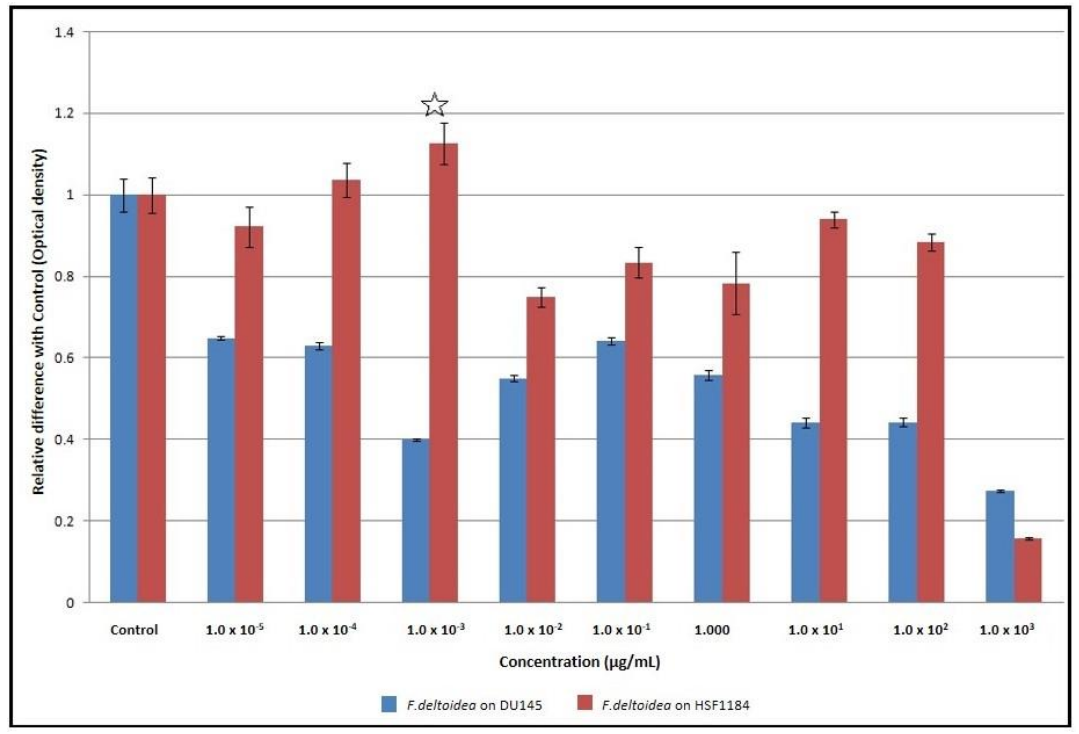

(a) 


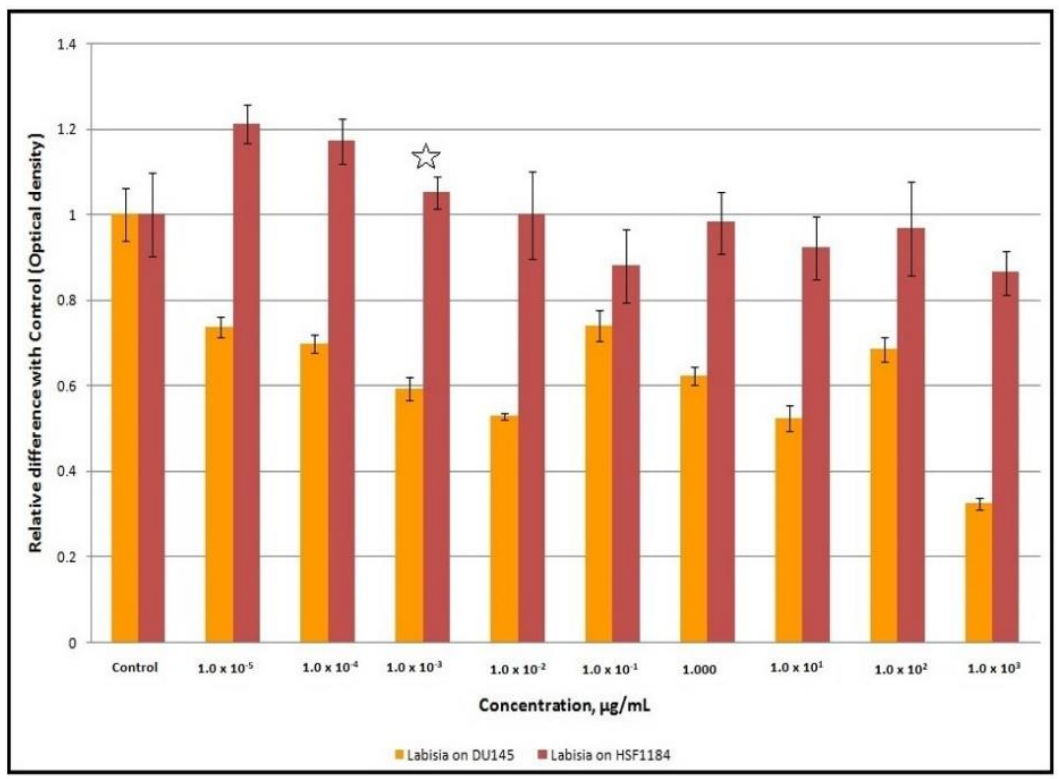

(b)

Figure 3: Comparative study shows the effect of aqueous extracts of (a) F. deltoidea and (b) L. pumila on human prostate carcinoma (DU145) and human fibroblast (HSF1184) cell lines. The statistical analysis of variances by ANOVA proved that there are significant differences between the DU145 and HSF1184 cell viability and concentration of the $F$. deltoidea aqueous extract, were the significant value $(\mathrm{P})$ was less than $0.05(\mathrm{P}<0.05)$.

The $F$. deltoidea extract significantly suppressed the proliferation of cancer cells at all concentrations. The results proved that different concentrations of the aqueous extract had varying efficacies towards the growth of cells. It is important to note that the effective concentration must not be toxic for the normal fibroblasts, i.e., HSF1184 (as control) cell line in this study. As shown in the Figure 3(a) the most effective antiproliferative concentration was $1 \times 10^{-3} \mu \mathrm{g} / \mathrm{mL}$ (against prostate cancer) in case of $F$. deltoidea aqueous extract while it boosted the growth of HSF1184 cell line.

Cells after treatment with aqueous extract of $L$. pumila are shown in Figure 3(b). The growth of the cells was found suppressed in almost all concentrations. The higher the concentration $\left(1 \times 10^{3}\right.$ $\mu \mathrm{g} / \mathrm{mL}$ ) of the extract, the more toxic it proved to be for the cancer cells resulting in lowest cell viability. This concentration was also tested on human fibroblasts however it did not allow them to thrive in the best possible way. It can be seen from the viability plot $3(\mathrm{~b})$ that $1 \times 10^{-3} \mu \mathrm{g} / \mathrm{mL}$ was the most effective concentration because it not only suppressed the growth of cancer cells but also encouraged the growth of normal cells. The cells treated with $L$. pumila extract were $\sim 42 \%$ less viable as compared to those that were not exposed to the phytoextract. Our results are compatible with the findings previously reported on the effect of $L$. pumila extracts on human fibroblast (HSF1184) cell line (30).

\section{Viability test in the presence of the extracts}

The viability test for prostate cancer DU145 cell line was performed in the presence of both extracts along with a negative control (cells that were not treated with any of the plant extracts) (Fig. 4). The plant extract concentration was $1 \times 10^{-3} \mu \mathrm{g} / \mathrm{mL}$ in both cases (see 3.2). This is a time dependant analysis to determine how the viable cell count changes with exposure to the extract. Moreover, it would reflect how much time does an extract need to kill all the cells? 


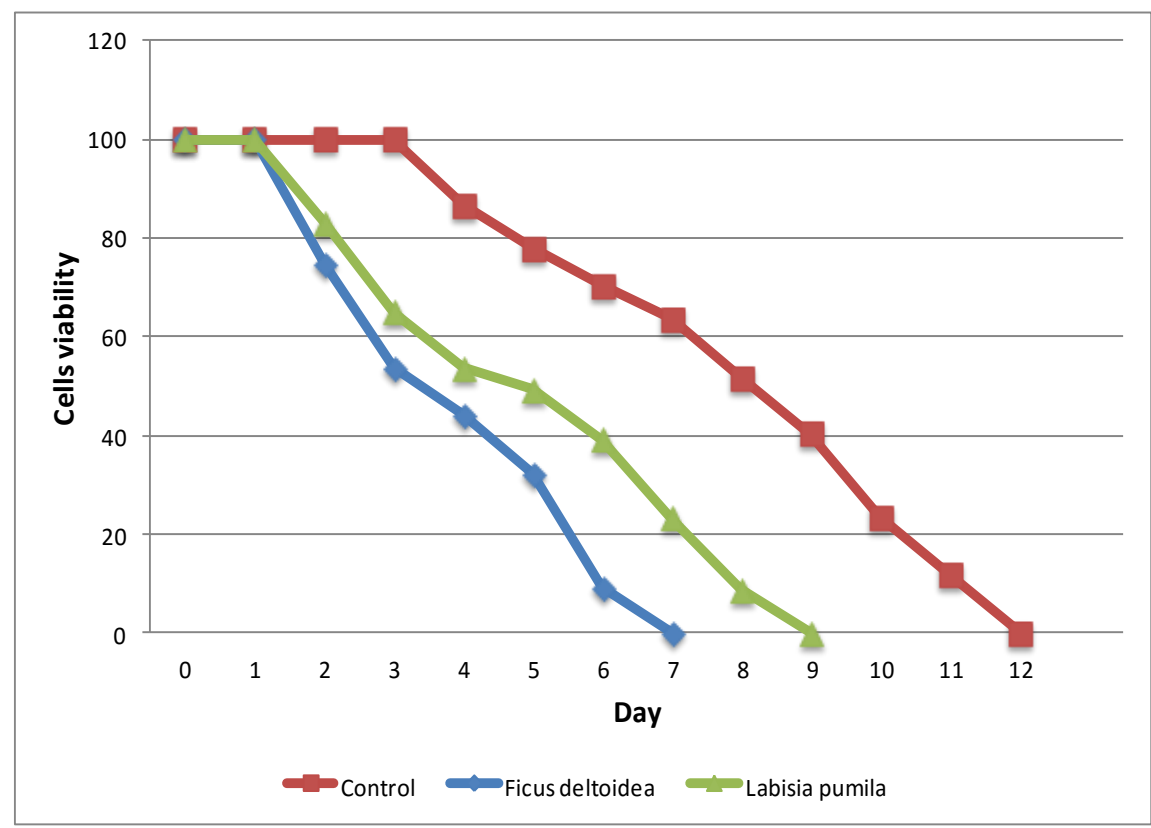

Figure 4: Effect of $F$. deltoidea and L. pumila aqueous extracts on the viability of the DU145 cells

The effect of $F$. deltoidea aqueous extract was apparent from day 2 as it reduced the cell viability to $\sim 74 \%$. On day 4 the viable count further reduced to $\sim 44 \%$ while the negative control cells just started to lose their viability. All the cells died after 7 days when the control was still observed to be $\sim 55-60 \%$ viable. The result proved that $F$. deltoidea extract sharply reduce the life span of prostate cancer cells, i.e. from 12 (control cells lost complete viability on day 12) to 7 days.

The potencies of $L$. pumila were also found to be affecting cell viability from day 2 onwards but they were less effective compared to $F$. deltoidea extract. The cell viability reduced to $\sim 83 \%$ on day 2 which further shrank to $\sim 53 \%$ on day 4 . The complete viability loss of cell with $L$. pumila extract was recorded on day 9. These results further comprehended the MTT assay findings (see 3.2) that $F$. deltoidea extract is more potent than $L$. pumila on DU145 cell line.

Morphological observation in the presence of the extracts

Acridine orange/ethidium bromide (AO/EB) staining aided with fluorescent microscopy was used to identify apoptosis-associated cell membrane changes during apoptosis of cancer cells (31). This method cannot only help in determining the morphology of cell over time but also accurately distinguish cells in different stages of apoptosis. The morphological investigations were performed to determine the effects of plant extracts on cancer cells (Fig. 5). It was seen that the cells reduced and clumped together irregularly. The appearance of cells also changed from hexagonal to an irregular shape i.e. round or cranate. The dead cells detached from the surface and kept floating in the medium. The apoptotic body (formation) analysis was performed by staining the cells with $\mathrm{EB} / \mathrm{AO}$ dye for both extracts and observed under a microscope. The results showed almost similar effects on cellular morphology, i.e. blabbing cells, chromatin condensation, apoptotic cells and late apoptotic body formation. The only difference found in this experiment was the fact that a relatively higher number of living cells were found in case of prostate carcinomas under the effect of $L$. pumila extract than $F$. deltoidea. 

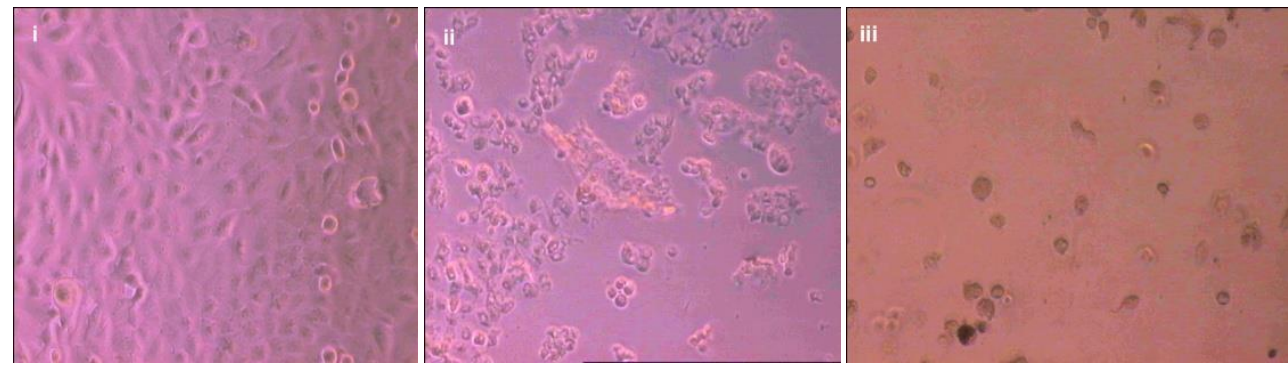

(a)
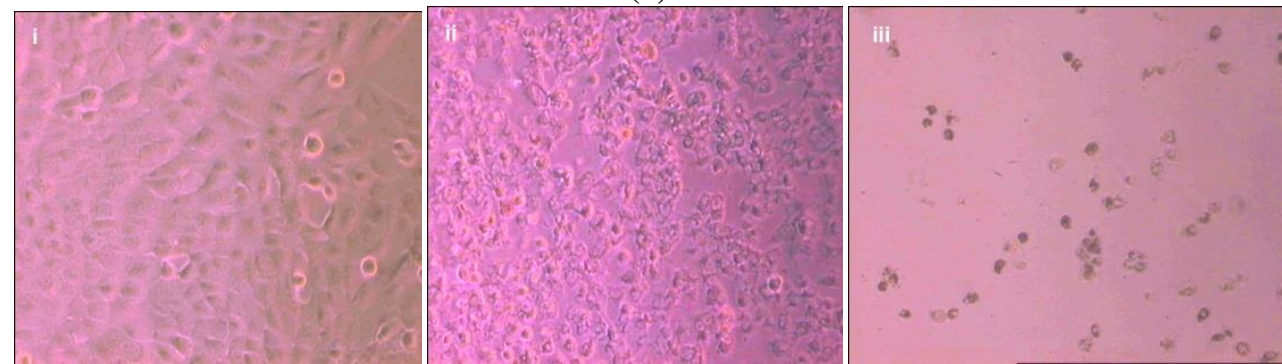

(b)
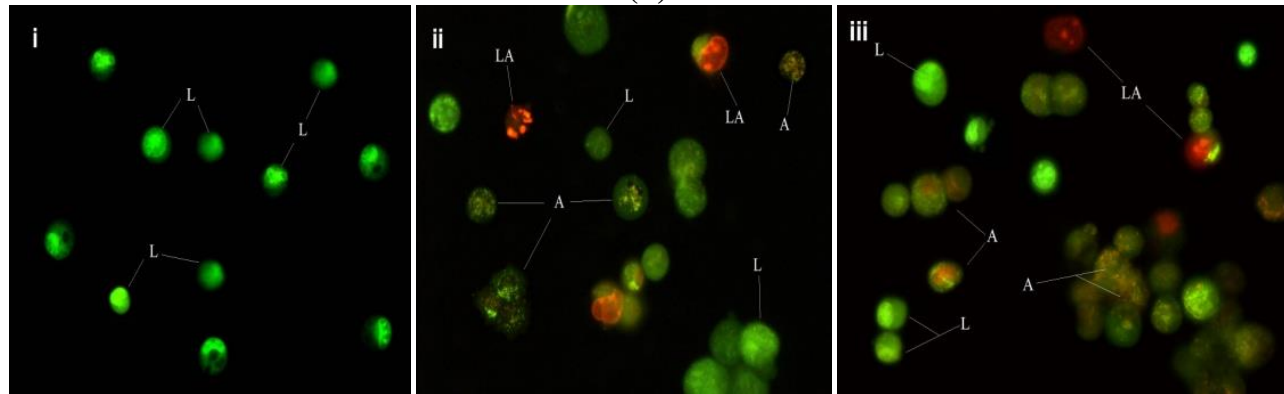

(c)

Figure 5: Effect of the extracts on the morphology of the cells (a) shows effect of $F$. deltoidea extract under inverted microscope (i) first day of treatment, (ii) fourth day of treatment, (iii) last day of treatment (viability $0 \%$ ), (b) shows effect of L. pumila extract under inverted microscope (i) first day of treatment, (ii) fourth day of treatment, (iii) last day of treatment (viability $0 \%$ ), and (c) shows the apoptotic body study of both extract (i) negative control, (ii) Effect of $F$. deltoidea extract, (iii) Effect of $L$. pumila extract. Note: ( $\mathrm{L}=$ Living cells, A= Apoptotic cells and LA= Late Apoptotic body)

Table 1: Summary of results: Effects of tropical plant extracts on human prostate carcinomas (DU145)

\begin{tabular}{|l|l|l|}
\hline & Ficus deltoidea & Labisia pumila \\
\hline Most Effective Concentration & $1 \times 10^{-3} \mu \mathrm{g} / \mathrm{mL}$ (OD 0.4) & $1 \times 10^{-3} \mu \mathrm{g} / \mathrm{mL}$ (OD 0.59) \\
\hline Complete Loss of Cell Viability & 7 days & 9 days \\
\hline $\begin{array}{l}\text { Morphological Observations } \\
\text { through Fluorescent Microscopy }\end{array}$ & $\begin{array}{l}\text { Appearance of blabbing cells, } \\
\text { apoptotic cells and late apoptotic } \\
\text { bodies }\end{array}$ & $\begin{array}{l}\text { Appearance of blabbing cells, } \\
\text { apoptotic cells and late apoptotic } \\
\text { bodies viable cells than Labisia } \\
\text { pumila }\end{array}$ \\
$\begin{array}{l}\text { More viable cells than Ficus } \\
\text { deltoidea }\end{array}$ \\
\hline Efficacy & $\begin{array}{l}\text { Relatively more potent than L. } \\
\text { pumila extract }\end{array}$ & $\begin{array}{l}\text { Relatively less potent than F. } \\
\text { deltoidea extract }\end{array}$ \\
\hline
\end{tabular}

\section{DISCUSSION}

The human prostate cells took 14 days to reach death phase and died completely. They needed 2 days to adapt to new conditions and express necessary enzymes to thrive, i.e. the lag phase. The cells entered log phase from day 3 and kept on growing exponentially until day 6 when maximum cell number was recorded with $100 \%$ viability. Population doubling time (PDT) of DU145 in the middle of the exponential phase was around one day $(24 \mathrm{~h})$ which is similar to the already reported 
doubling time (24-31 h) for prostate cancer cells (28). The cells reached the stationary phase on day 8 while the accumulation of toxic waste products and depletion of nutrients initiated the death phase from $9^{\text {th }}$ day onward. The cell viability became zero at day 14. This was important to determine lifecycle of these cell lines for maintenance and further assays.

Phytochemicals are natural bioactive compounds found in the roots, flowers, fruits and leaves of (medicinal) plants. The main purpose of these bioactive compounds in plants is to protect them against diseases (32). The herbs used in this study are reported to contain a number of bioactive ingredients that act against diseases like watery lung, diabetes, high blood pressure, diarrhoea and cancer (33). We observed that both of the phytoextracts significantly checked the growth of prostate cancer cells with however varying potencies.

The $L$. pumila extract proved as a natural anticancer bioreagent due to the fact that it contains flavonoids and other phenolic acids in abundance (34). These compounds showed great potential as antineoplastic agents $(34,35)$. L. pumila is plentiful in resorcinols, flavonoids and phenolic compounds, i.e. gallic acid, myrecetin, kaempherol and catechin (36-38). These bioactive phytochemicals equip the plant with anti-proliferative activity against prostate cancer. Daniel et al. provided the evidence for the anticancerous properties of $L$. pumila on prostate cancer cell line PC3 The study has clearly indicated that epigallocatechin was able to inhibit PC-3 prostate cancer cell proliferation via MEKindependent ERK1/2 activation (21). While in this investigation we used DU145 cell line to show the suppressive effect of the phytoextract on the cell viability and propose the same mode of action.

$F$. deltoidea has a rich supply of polyphenolics, flavonoids (such as Genistin), alkaloids (such as antofine) and tannins. Plant polyphenols are already well-known for their antioxidative capacities and their use may prevent oxidative stress, associated with diseases such as cancer (39-42). Flavonoids such as epicatechin, myricetin, naringenin and flavonoid glucosides identified as quercetin 5,4'-diO-beta-Dglucopyranoside and quercetin-3rutinoside had been isolated from leaves of $F$. deltoidea (15). A high amount of epicatechin found in leaves might be responsible for the strong radical scavenging activities found in the extract. The presence of a number of potent phytochemicals may be the reason for its strong antioxidant and/or antineoplastic capacity of $F$. deltoidea resulting in a rather rapid and effective killing of prostate cancer cells in comparison with $L$. pumila $(15,33$, 43, 44).

Apoptosis is the terminal event in the biology of cells during which the cell components are transformed into apoptotic bodies. It is the major type of programmed cell death embarked by changes in the cell membrane. The early event of the apoptosis includes the exposure of phosphotidylserine on the cell membrane. The plasma membrane integrity is severely compromised during late apoptotic stages $(45,46)$. The prostate cancer cells under the effect of the tropical plant extracts (in this work) showed the blabbing of outer wall of plasma membrane hinting toward the fact that apoptosis had already kickedoff. DNA (chromatin) condensation seen in our experiment further strengthened the fact that apoptotic machinery had been activated in cancer cells.

Herbal medicine can revolutionize modern drug development. They do have obvious advantages, e.g. inroads towards inexpensive remedies, rapid discovery of new drugs and synergy between various components of herbs. The main disadvantage is the lack of international standardization for the evaluation of composition, efficacy, safety, quality, regulation and approval of these medicines $(32,47)$. To put in a nutshell the amalgamation of traditional and modern medicine can pave the way towards a better healthcare in the era of deadly diseases like cancer.

\section{CONCLUSION}

F. deltoidea and L. pumila are two important tropical plants being used in traditional medicine for decades. The aqueous extracts of these plants were promising in effectively killing the cancer cell line with $F$. deltoidea being more potent than $L$. pumila. They have the ability to inhibit the growth and henceforth can be used as alternative medicine to treat cancers with less cytotoxicity risks to normal cells of the body.

\section{REFERENCES}

1.Balandrin MF, Kinghorn AD, Farnsworth NR. Plant-Derived Natural Products in Drug Discovery and Development. In: Human Medicinal Agents from plants. 2009. p. 2-12. 
2.Fridlender M, Kapulnik Y, Koltai H. Plant derived substances with anti-cancer activity: from folklore to practice. Frontiers in Plant Science. 2015;6:1-9.

3.Trendowski M. Recent Advances in the Development of Antineoplastic Agents Derived from Natural Products. Drugs. 2015;75(17):19932016.

4.Ekor M. The growing use of herbal medicines: issues relating to adverse reactions and challenges in monitoring safety. Frontiers in Pharmacology. 2013;4:177.

5.Farnsworth NR, Akerele O, Bingel AS, Soejarto DD, Guo Z. Medicinal plants in therapy. Bulletin of the World Health Organization. 1985;965-981.

6.Newman DJ, Cragg GM. Natural products as sources of new drugs over the 30 years from 1981 to 2010. Journal of natural products. 2012;75(3):311-335.

7.Ahmad I, Aqil F, Ahmad F, Owais M. Herbal Medicines: Prospects and Constraints. WileyVCH Verlag GmbH \& Co. KGaA; 2006. p. 59-77.

8.Cragg GM, Newman DJ. Plants as a source of anti-cancer agents. 2005;100:72-79.

9.Graham JG, Quinn ML, Fabricant DS, Farnsworth NR. Plants used against cancer - an extension of the work of Jonathan Hartwell. J Ethnopharmacol. 2000;73:347-377.

10.Hartwell JL. Plants used against cancer. A survey. Lloydia. 1971;34(4):386-425.

11.Huda-Faujan N, Noriham a, Norrakiah aS, Babji aS. Antioxidative activities of water extracts of some malaysian herbs. International Food Research Journal. 2007;14(1):61-68.

12.Wagner WL, Herbst DR, Sohmer SH. Manual of the Flowering Plants of Hawai'i, Vols. 1 and 2: University of Hawai'i and Bishop Museum Press; 1999.

13. Bunawan H, Amin NM, Bunawan SN, Baharum SN, Mohd Noor N. Ficus deltoidea Jack: A review on its phytochemical and pharmacological importance. Evidence-Based Complementary and Alternative Medicine. 2014.

14.Sulaiman MR, Hussain MK, Zakaria ZA, Somchit MN, Moin S, Mohamad AS, et al. Evaluation of the antinociceptive activity of Ficus deltoidea aqueous extract. Fitoterapia. 2008;79(7-8):557-561.

15.Dzolin S, Ahmad R, Mat Zain M, Ismail MI. Flavonoid distribution in four varieties of Ficus deltoidea ( Jack ). Journal of Medicinal Plant and Herbal Therapy Research. 2015;3:1-9.
16.Kumar S, Pandey AK. Chemistry and biological activities of flavonoids: an overview. TheScientificWorldJournal. 2013;2013:162750.

17.Ong SL, Ling aPK, Poospooragi R, Moosa S. Production of Flavonoid compounds in cell cultures of Ficus deltoidea as influenced by medium composition. International Journal of Medicinal and Aromatic Plants. 2011;1(2):62-74.

18. Chua LS, Lee SY, Abdullah N, Sarmidi MR. Review on Labisia pumila (Kacip Fatimah): bioactive phytochemicals and skin collagen synthesis promoting herb. Fitoterapia. 2012;83(8):1322-1335.

19.Wan Ezumi MF, Amrah SS, Suhaimi AWM, Mohsin SSJ. Evaluation of the female reproductive toxicity of aqueous extract of Labisia pumila var. alata in rats. Indian Journal of Pharmacology. 2007;39(1):30.

20.Runi SP. Studies on medicinal plant in Sarawak. In: Seminar on Medicinal and Aromatic Plants, Kuala Lumpur (Malaysia), 12-13 Sep 2000: Forest Research Institute Malaysia (FRIM).

21.Adlercreutz H. Phyto-oestrogens and cancer. Lancet Oncol. 2002;3(6):364-373.

22.Facts C. Cancer Facts \& Figures. 2015.

23.Malvezzi M, Bertuccio P, Rosso T, Rota M, Levi F, La Vecchia C, et al. European cancer mortality predictions for the year 2015: does lung cancer have the highest death rate in EU women? Annals of oncology : official journal of the European Society for Medical Oncology / ESMO. 2015;26(4):779-786.

24.Malvezzi M, Bertuccio P, Levi F, La Vecchia C, Negri E. European cancer mortality predictions for the year 2014. Annals of Oncology. 2014;25(8):1650-1656.

25.Ferlay J, Shin H-R, Bray F, Forman D, Mathers C, Parkin DM. Estimates of worldwide burden of cancer in 2008: GLOBOCAN 2008. Int J Cancer. 2010;127(12):2893-2917.

26.Freshney RI. Culture of Animal Cells: A manual of basic techniques. 5 ed: John Wiley \& Sons, Inc.; 2005.

27.Cohen JJ. Apoptosis. Immunology Today. 1993;14(3):126-130.

28.Schwab TS, Stewart T, Lehr J, Pienta KJ, Rhim JS, Macoska Ja. Phenotypic characterization of immortalized normal and primary tumor-derived human prostate epithelial cell cultures. The Prostate. 2000;44(2):164-171.

29.Riss TL, Moravec RA. Use of multiple assay endpoints to investigate the effects of incubation time, dose of toxin, and plating density in cell- 
based cytotoxicity assays. Assay Drug Dev Technol. 2004;2(1):51-62.

30.Mukrish M. The photoprotective and collagen stimulatory effects of labisia pumila var pumila extract on UVB irradiated human skin fibroblast (HSF1184) cells. Universiti Teknologi Malaysia; 2012.

31.Liu K, Liu P-c, Liu R, Wu X. Dual AO/EB Staining to Detect Apoptosis in Osteosarcoma Cells Compared with Flow Cytometry. Medical Science Monitor Basic Research. 2015;21:15-20.

32.Benzie IFF, Wachtel-Galor S. Herbal medicine: biomolecular and clinical aspects. 2 ed: CRC Press; 2011.

33.Mustapha Z, Harun H. Phytochemical constituents in leaves and callus of Ficus deltoidea Jack. Walailak Journal of Science and Technology (WJST). 2014;12(5):431-439.

34.Manda V, Dale OR, Awortwe C, Ali Z, Khan IA, Walker LA, et al. Evaluation of drug interaction potential of Labisia pumila (Kacip Fatimah) and its constituents. Frontiers in Pharmacology. 2014;5(178).

35.Karimi E, Jaafar HZE. HPLC and GC-MS determination of bioactive compounds in microwave obtained extracts of three varieties of labisia pumila benth. Molecules. 2011;16(8):6791-805.

36.Chua LS, Latiff NA, Lee SY, Lee CT, Sarmidi MR, Aziz RA. Flavonoids and phenolic acids from Labisia pumila (Kacip Fatimah). Food chemistry. 2011;127(3):1186-1192.

37.Karimi E, Jaafar HZE, Ahmad S. Phytochemical analysis and antimicrobial activities of methanolic extracts of leaf, stem and root from different varieties of labisa pumila benth. Molecules. 2011;16(6):4438-4450.

38.Norhaiza M, Maziah M, Hakiman M. Antioxidative properties of leaf extracts of a popular Malaysian herb, Labisia pumila. Journal of Medicinal Plants Research. 2009;3(4):217-223.

39.Azura N. The survival and growth of human ovarian carcinoma cell line post treatment with Ficus deltoidea extracts. Universiti Teknologi Malaysia; 2011.

40.Manach C, Scalbert A, Morand C, Remesy C, Jimenez L. Polyphenols: food sources and bioavailability. The American journal of clinical nutrition. 2004;79(5):727-747.

41.Rice-Evans CA, Miller NJ, Paganga G. Structure-antioxidant activity relationships of flavonoids and phenolic acids. Free radical biology \& medicine. 1996;20(7):933-956.
42.Valko M, Leibfritz D, Moncol J, Cronin MTD, Mazur M, Telser J. Free radicals and antioxidants in normal physiological functions and human disease. The international journal of biochemistry \& cell biology. 2007;39(1):44-84.

43.Misbah H, Aziz AA, Aminudin N. Antidiabetic and antioxidant properties of Ficus deltoidea fruit extracts and fractions. BMC complementary and alternative medicine. 2013;13(1):118-126.

44.Norra I. Free radical scavenging activity and phenolic content of Ficus deltoidea accessions MFD4 and MFD6 leaves. Development. 2011;39(1):85-92.

45.Gobe G, Zhang XJ, Cuttle L, Pat B, Willgoss D, Hancock J, et al. Bcl-2 genes and growth factors in the pathology of ischaemic acute renal failure. Immunology and Cell Biology. 1999;77(3):279286.

46.Jinesh GG, Choi W, Shah JB, Lee EK, Willis DL, Kamat AM. Blebbishields, the emergency program for cancer stem cells: sphere formation and tumorigenesis after apoptosis. Cell death and differentiation. 2013;20(3):382-395.

47.Chawla R, Thakur P, Chowdhry A, Jaiswal S, Sharma A, Goel R, et al. Evidence based herbal drug standardization approach in coping with challenges of holistic management of diabetes: a dreadful lifestyle disorder of 21 st century. Journal of Diabetes and Metabolic Disorders. 2013;12(1):12-35.
Received: January 15, 2016; Accepted: April 25, 2016 